\title{
Effects of Dredging Operations on Fishing Sites in the Niger Delta Basin Nigeria
}

\author{
Ibeawuchi C Nze ${ }^{1 *}$, Geradine N Okeudo ${ }^{2}$, Nnenna J Nze ${ }^{3}$ and Declan N Dike ${ }^{4}$ \\ ${ }^{1}$ Department of Maritime Management, Technology, Federal University of Technology, Nigeria \\ ${ }^{2}$ Department of Transport Management Technology, Federal University of Technology, Nigeria \\ ${ }^{3}$ Centre for Logistics and Transport Studies, University of Port Harcourt, Nigeria \\ ${ }^{4}$ Department of Transport Management Technology, Federal University of Technology, Nigeria
}

Submission: January 17, 2018; Published: April 26, 2018

Corresponding author: Ibeawuchi C Nze, Department of Maritime Management, Technology, Federal University of Technology, Owerri, Nigeria, Email: elibechibu@yahoo.com

\begin{abstract}
The study examines the ecological and economic implications of dredging activities on fishing sites in the Niger Delta area of Nigeria. Data from secondary sources were empirically analysed and results show that dredging operations have significant effect on fishing sites. These are revealed by the magnitude of ecological and economic implications to the region, which is reflected by the level of economic value of damage caused by dredging in the area, the number of fishing sites and farm lands affected by the dredging operations. The study concludes that even though dredging is imperative for the economic survival of the area, there is need for routine studies to be conducted prior to the operations so as to ensure that dredging activities are executed in the most environmentally friendly manner in accordance to international best practices in order to mitigate ecological imbalance in the basin.
\end{abstract}

Keywords: Ecology; Economics; Dredging; Fishing; Niger delta; Basin

\section{Introduction}

The area politically known as the Niger delta is situated within the south-south, partly south-East and South-West regions of Nigeria. It extends over $70,000 \mathrm{~km} 2$ and accounts for about $7.5 \%$ of Nigeria's land mass. Historically, the Niger delta consists of the present day Bayelsa, Delta and Rivers states, and recently Abia, Akwa-Ibom, Cross Rivers, Edo, Imo and Ondo states (Wikipedia, 2017). Geographically, the Niger delta is the delta of Niger River at the Gulf of Guinea on the Atlantic Ocean in Nigeria. Remarkably, the Niger delta is a coastal region of global environmental and economic importance, being one of the largest mangrove forests in the world, Africa's largest and the world's third largest delta (Wikipedia, 2017).

In furtherance, it is described as the most extensive fresh water swamp forests with a mosaic of diverse and sensitive ecosystems which transverse four vegetations zones in west and central Africa.

The major economic and occupational activities of the Niger Delta people include fishing, farming, hunting and palm oil production. Those residing in the coastal area are preoccupied with fishing while the upland inhabitants are pre-occupied with farming and palm oil production. This pre supposes that any human activity that poses an imbalance to the ecosystem of the area, may invariably affect the economic well being of the inhabitants. Dredging is one of such activities. Løkkeborg [1] posits that dredging is often carried out to create access for oil exploration, marine transportation and water borne commerce. The discovery of oil in the 50's have increased dredging and associated activities in the area, and thus supports the assertion of Akegbejo- Samsons [2] that dredging in sensitive ecosystems may have serious impacts if not well managed because of the dredged materials and their disposal.

Hence this study attempts to bridge these research gaps by the examination of the extent of ecological and economic effect of dredging and the fishing sites and farms in the Niger delta area of Nigeria.

\section{Objectives}

The specific objectives of this study include:

I. To examine the extent to which dredging activities affect fishing sites in the Nigeria Delta

II. To evaluate the extent to which dredging activities affect farming in the Niger Delta. 
III. To determine the level of significance of the area dredged in respect of economic loss arising from dredging activities in the Niger Delta.

\section{Research questions}

The following questions are asked in order to proffer solutions to the problem of this study.

I. To what extent does dredge activities affect fishing sites and ecosystem of the Niger Delta?

II. To what extent does dredging activities affect farming and ecosystem of the Niger Delta?

III. Is the area dredged significant to economic loss arising from dredging activities in the Niger Delta?

\section{Hypotheses}

The tentative answers to the research questions asked in this study include:

I. Ho1: Dredging activities have no significant effect on the fishing sites and ecology of the Niger Delta.

II. Ho2: dredging activities have no significant effect on farming and ecology of the Niger Delta.

III. Ho3: The area dredged is not significant to economic loss arising from dredging activities in the Niger Delta.

\section{Review of related literature}

Dredging in sensitive environments as conveyed by Ade [3], Ohimain et al., Enger \& Bradley [4]; and Edy \& Ukpong [5] is often accompanied by ecological impacts including damage to Flora and Fauna; alteration of coastal topography and hydrology as well as impairment of water quality. They further agree that dredging virtually affects all components of the environment including zooplankton, phytoplankton, benthic invertebrates and the vegetation at large. In addition, it has been revealed that dredging and associated operations result to widespread hydrological changes resulting to coastal retreat. Hence, dredging may disrupt the dynamic interrelationship between environmental components and socio- economic functions of the coastal areas which may disrupt the ecological equilibrium.

The problems associated with dredging in respect of the environment are revealed in the works of Bray et al. [6] which affirms that dredging causes environmental changes, especially anthropogenic impacts on landscape that causes the accumulation of sediments in depositional sites in lakes, rivers and estuaries. Ehrlich \& Anne [7] assert that dredged up pollutants dumped at designated locations increase the chance of contaminants straying into such areas that were initially free from contaminants. These contaminants which may be acidic in nature spread out to adjacent farms thereby affecting cropyields. On the other hand, the studies of Mercaldo- Allen \& Goldberg [8] and Løkkeborg [1] further confirms that dredging affects fish species, as it is revealed that fish species in the un- dredged locations were found to be generally in a better condition than those in the dredged locations.
In summary, the effects of dredging on aquatic organisms have been a source of environmental concern for decades as it affects not only the mortality of fish and shell fish entrained during the dredging process but the adjourning farm lands and crop yields. Supportively, Ashton-Jones [9] concludes that dredging and associated activities could disrupt fisheries and may as well damage spawning grounds which result to serious impacts on vital fishery resources and invariably the fishing industry at large.

\section{Materials and Methods}

Data for this research was solely collated from secondary sources, particularly from the Shell bulletin and the publications of the Niger Delta Development Commission (NDDC). The data were subjected to econometric methods of multiple linear regression analysis in order to determine the empirical relationship that may exist among the variables defined as follows:

1. $\mathrm{ADG}=$ Area dredged in square kilometres $(\mathrm{km} 2)$, a proxy for dredging activities in the Niger Delta.

2. $\quad \mathrm{ECV}=$ Economic Value of damage caused by dredging activities in the Niger Delta, in millions of naira (Nm); a proxy for the economic effects of dredging activities.

3. $\quad$ FSS $=$ Fishing sites affected by dredging activities in the Niger Delta, a proxy for the effect on the fishing industry.

4. $\quad$ FLD $=$ The number of farm lands affected by dredging activities in the Niger Delta, a proxy for the ecological effect on the area.

5. $\mu=$ The disturbance variable denoted as Error term.

While ECV is the dependent variable, ADG, FSS and FLD represent the independent variables respectively.

\section{Data Presentation}

Table 4.1: Economic Effects of Dredging on Fisheries and Farms.

\begin{tabular}{|c|c|c|c|c|}
\hline Year & $\begin{array}{c}\text { Dredged } \\
\text { Area (Km } \mathbf{2} \text { ) }\end{array}$ & $\begin{array}{c}\text { Economic Value } \\
\text { of damage (Nm) }\end{array}$ & $\begin{array}{c}\text { Fishing Sites } \\
\text { Affected }\end{array}$ & $\begin{array}{c}\text { Farmlands } \\
\text { Affected }\end{array}$ \\
\hline 2010 & 145.62 & 12365820 & 160 & 124 \\
\hline 2011 & 213.4 & 15732900 & 164 & 126 \\
\hline 2012 & 856.77 & 22621800 & 182 & 136 \\
\hline 2013 & 563.36 & 34821700 & 78 & 230 \\
\hline 2014 & 338.25 & 39923600 & 56 & 120 \\
\hline 2015 & 158.51 & 25463820 & 187 & 134 \\
\hline 2016 & 223.1 & 40325324 & 170 & 252 \\
\hline 2017 & 759.6 & 43651836 & 285 & \\
\hline
\end{tabular}

Source: Compiled from shell Bulletins and NDDC Publications.

Table 4.1 shows the annual statistics of the area dredged, the economic value of damage arising from dredging activities, the number of farms affected by dredging activities in the Niger Delta area of Nigeria. 


\section{Data analysis}

Table 4.2 shows the correlations of the dependent variable and independent variables. The correlation matrix reveals that positive correlation exists between the Economic values of damage arising from dredging activities and the Area dredged as well as the Fishing sites and farm lands affected by dredging in the Niger Delta.

Table 4.2: Correlations

\begin{tabular}{|c|c|c|c|c|c|}
\hline \multicolumn{1}{|c|}{} & ECV & ADG & FSS & FLD \\
\hline \multirow{4}{*}{$\begin{array}{c}\text { Pearson } \\
\text { Correlation }\end{array}$} & ECV & 1.000 & .505 & .718 & .731 \\
\cline { 2 - 6 } & ADG & .505 & 1 & .281 & .622 \\
\cline { 2 - 6 } & FSS & .718 & .281 & 1.000 & .304 \\
\cline { 2 - 6 } & FLD & .731 & .622 & .304 & 1 \\
\cline { 2 - 6 } & ECV &. & .101 & .022 & .020 \\
\hline \multirow{4}{*}{$\begin{array}{c}\text { Sig. } \\
\text { (1-tailed) }\end{array}$} & ADG & .101 &. & .250 & .050 \\
\cline { 2 - 6 } & FSS & .022 & .250 &. & .232 \\
\cline { 2 - 6 } & FLD & .02 & .050 & .232 &. \\
\cline { 2 - 6 } & ECV & 8 & 8 & 8 & 8 \\
\hline \multirow{4}{*}{$\mathrm{N}$} & ADG & 8 & 8 & 8 & 8 \\
\cline { 2 - 6 } & FSS & 8 & 8 & 8 & 8 \\
\cline { 2 - 6 } & FLD & 8 & 8 & 8 & 8 \\
\hline
\end{tabular}

Source: SPSS V.20 Software.
Table 4.3 describes the variables entered/ removed for the analysis. It describes the dependent and independent variables as removed and entered respectively.

Table 4.3: Variables Entered/Removed ${ }^{a}$

\begin{tabular}{|c|c|c|c|}
\hline Model & Variables Entered & Variables Removed & Method \\
\hline 1 & FLD, FSS, ADGb & $\cdot$ & Enter \\
\hline
\end{tabular}

a. Dependent Variable: ECV

b. All requested variables entered.

Source: Software Output.

Table 4.4 shows the characteristics of the model as summarized. It reveals a model with a coefficient of determination R2 value of 0.804 which implies that the regression line gives a good fit to the observed data, since this line explains $80.4 \%$ of the total variation of the ECV values around their mean. Therefore, the remaining $19.6 \%$ of the total variation in the dependent variable, ECV is un accounted for by the regression line and is attributed to the factors included in the disturbance variable denoted as Error term, $\mu$.The DurbinWatson value of 2.505 reveals that there is no autocorrelation in the relationship.

Table 4.4: Model Summaryb

\begin{tabular}{|c|c|c|c|c|c|c|c|c|c|c|}
\hline \multirow{2}{*}{ Model } & \multirow{2}{*}{$\mathbf{R}$} & \multirow{2}{*}{ R Square } & \multirow{2}{*}{$\begin{array}{c}\text { Adjusted R } \\
\text { Square }\end{array}$} & \multirow{2}{*}{$\begin{array}{c}\text { Std. Error of the } \\
\text { Estimate }\end{array}$} & \multicolumn{4}{|c|}{ Change Statistics } & Durbin-Watson \\
\cline { 6 - 11 } & & & R Square Change & F Change & df1 & df2 & Sig. F Change & \\
\hline 1 & $.897^{\mathrm{a}}$ & 0.804 & 0.658 & 9025312.194 & 0.804 & 5.481 & 3 & 4 & 0.067 & 2.505 \\
\hline
\end{tabular}

a. Predictors: (Constant), FLD, FSS, ADG

b. Dependent Variable: ECV

Source: Software Output.

Table 4.5 shows the Analysis of variance (ANOVA) for the variables. The $\mathrm{F}$ ratio indicates the effect of the independent variables on the model. The value of 5.481 is greater than 1 and therefore is an indication that there is no sampling error. At 0.067

Table 4.5: ANOVAa

\begin{tabular}{|c|c|c|c|c|c|c|}
\hline \multicolumn{2}{|c|}{ Model } & Sum of Squares & Df & Mean Square & F & Sig. \\
\hline \multirow{3}{*}{1} & Regression & 1339386660405992.500 & 3 & 446462220135330.800 & 5.481 & $.067^{\mathrm{b}}$ \\
\cline { 2 - 8 } & Residual & 325825040771200.800 & 4 & 81456260192800.200 & & \\
\cline { 2 - 8 } & Total & 1665211701177193.200 & 7 & & & \\
\hline
\end{tabular}

a. Dependent Variable: ECV

b. Predictors: (Constant), FLD, FSS, ADG

Source: Software Output.

Table 4.6 shows the coefficients of the model and reveals their degree of statistical significance of the independent variables to the dependent variable. The t- test reveals that Area dredged, ADG is not significant in the model with a value of 0 which is less than 2 since it falls within the acceptance region; hence we accept the null hypothesis that the area dredged has no significant effect on the economic value of damage from dredging. The Fishing sites

level of significance, we can infer that out of 93.3 cases the difference between the mean is not by chance but genuine, as indicated in the table. 
Table 4.6: Coefficientsa .

\begin{tabular}{|c|c|c|c|c|c|c|}
\hline & \multirow{2}{*}{ Model } & \multicolumn{2}{|c|}{ Unstandardized Coefficients } & \multirow{2}{*}{$\begin{array}{c}\text { Standardized Coefficients } \\
\text { Beta }\end{array}$} & \multirow[t]{2}{*}{$\mathbf{t}$} & \multirow[t]{2}{*}{ Sig. } \\
\hline & & B & Std. Error & & & \\
\hline \multirow{4}{*}{1} & (Constant) & -39104641.66 & 11786858 & & -3.318 & .029 \\
\hline & $\mathrm{ADG}$ & 4.815 & 15559.236 & 0 & 0 & 1 \\
\hline & FSS & 119993.95 & 51404.457 & 0.546 & 2.334 & .080 \\
\hline & FLD & 163048.465 & 82833.802 & 0.564 & 1.968 & .120 \\
\hline
\end{tabular}

a. Dependent Variable: ECV

Source: Software output.

\section{Discussion}

Prior to the discovery of crude oil in commercial quantities in the 50s in the Niger Delta, the people relied on their serene marine environment for sustenance. They made their living from exploitation of the waters, land and tropical as well as mangrove vegetations adjacent to their homes. They had strong attachment to their environment. However, the economic activities of the people were soon distorted as a result of environmental degradation occasioned by oil exploration and pollution as well as increased marine transportation and dredging activities. These activities have seemingly made life difficult for the coastal and riverside inhabitants of the Niger Delta.

In the light of the above, the salient issues addressed in this study were:

A. The examination that dredging activities affect fishing sites in the Niger Delta

B. The evaluation that dredging activities affect farming in the Niger Delta; and

C. The determination that the area dredged has no significant effect on the economic value of damage from dredging in the Niger Delta.

The results in Table 4.5 reveals that the Fishing sites and Farmlands affected by dredging activities are significant in the model with t- test values of 2.334 and 1.968 respectively as they fall within the critical region. These answers the first and second objectives of this study and the corresponding research questions which led to the rejection of the null hypotheses that dredging activities has no significant effect on the fishing sites and that dredging activities has no significant effect on farmlands in the Niger delta. Therefore, the results of the analysis reveal significant effects of dredging activities on both fishing sites and farmlands in the Niger Delta. This is strongly supported by the works of Bray et al. [6] and Mercaldo- Allen \& Goldberg [8] that respectively posit that dredging causes environmental changes and increased contaminants.

The third research question of this study tends to be answered by the outcome of the analysis as shown in Table 4.5 which indicates that the Area dredged, ADG is not significant in the model with a value of 0 which is less than 2 as it fell within the acceptance region. This led to the acceptance of the null hypothesis that the area dredged has no significant effect on the economic value of damage from dredging. This result is contradicted by the work of Houton et al. [10] who reported that dredging has significant effect on the mangrove area. More so, the studies of Løkkeborg [1]; Lenihan \& Peterson [11] further confirms that dredging affects fish species, as it is revealed that fish species in the un- dredged locations were found to be generally in a better condition than those in the dredged locations [12].

\section{Conclusion}

This study concludes that dredging activities have significant effect on fishing sites and farmlands in the Niger Delta as indicated by the positive correlation between the economic values of damage from dredging and the fishing sites and farmlands affected. It is also concluded that the area dredged have no significant effect on the economic value of damage from dredging. Finally, the study concludes that even though dredging is imperative for the economic survival of the area, there is need for routine studies to be conducted prior to the operations so as to ensure that dredging activities are executed in the most environmentally friendly manner in accordance to international best practices so as to mitigate ecological imbalances in the basin.

\section{References}

1. Løkkeborg S (2005) Impacts of Trawling and Scallop Dredging on Benthic Habitats and Communities. FAO Fish Technical Paper No 472: 58.

2. Akegbejo- Sampson YA (2007) The Inner Niger Delta Project: Environmental, Social and Economic Consequences of Dredging the Lower Niger River on the Communities. $10^{\text {th }}$ International River Symposium and Environmental Flows Conference, Brisbane Australia.

3. Ade S (1998) Dredging Impact Study: A Report Submitted to Shell Petroleum Development Company (SPDC), Warri Ade Sobande and Associates.

4. Enger DE, Bradley FS (1992) Environmental Science: A Study of Inter Relationships. Wm Brown Publishers, London, England.

5. Eddy NO, Ukpong IJ (2005) Heavy Metals Concentration in Upper Calabar River Sediments, South Eastern Nigeria. African Journal of Environmental Pollution Health 4(1): 38-43.

6. Bray RB (2001) Dredging. Oxford. Butterworth.

7. Ehrlich RP, Anne HE (1991) Healing the Planet. Addison Wesley Publishing Company, Inc. USA.

8. Mercaldo- Allen R, Goldberg R (2011) Review of the Ecological Effects of Dredging in the Cultivation and Harvest of Molluscan Shellfish. NOAA Technical Memorandum NMFS- NE- 220. National Marine Fisheries Service, Milford, Connecticut, USA 06460. 
9. Ashton- Jones N (1998) The Human Ecosystems of the Niger Delta: An ERA Handbook. Environmental Rights Action, Benin City, Nigeria, pp. 224

10. Hauton C, Atkinson RJA, Moore PG (2003) The Impact of Hydraulic Blade dredging on a Benthic Megafaunal Community in the Clyde Sea Area, Scotland. Journal of Sea Res 50(1): 45-56.
11. Lenihan HS, Peterson CH (2004) Conserving Oyster reef Habitat by Switching from Dredging and Tonging to Diver- Harvesting. Fish Bulletin 102(2): 298-305.

12. Bray RB (2009) Environmental Aspect of Dredging. Taylor and Francis Group, London, UK, England.

Your next submission with Juniper Publishers will reach you the below assets

- Quality Editorial service

- Swift Peer Review

- Reprints availability

- E-prints Service

- Manuscript Podcast for convenient understanding

- Global attainment for your research

- Manuscript accessibility in different formats

( Pdf, E-pub, Full Text, Audio)

- Unceasing customer service

Track the below URL for one-step submission https://juniperpublishers.com/online-submission.php 